\section{Tilbake til kardiologiens kilder}

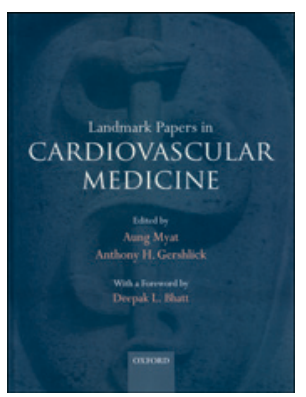

De to britiske redaktørenes opplegg er meget ambisiøst. En stor gruppe junioreksperter screenet kardiologisk litteratur fra hele verden fra de siste 40 år. Via en komplisert seleksjonsprosess har man så valgt ut ti nøkkelartikler innen hvert av de 26 utvalgte fagfeltene. Disse nøkkelartiklene er så presentert av seniorforfattere i kortform og forsynt med bakgrunnskommentarer og en vurdering av hvorfor disse var så viktige for utviklingen og for dagens praksis.

Resultatet er blitt en meget tiltalende publikasjon. Kortversjonene gjør originalarbeidene lett tilgjengelige. I bokser med lærepunkter oppsummeres konklusjonene i hver artikkel. Styrke og begrensninger fremheves. Fremtidig utvikling kommenteres også. Dette er en utmerket måte å skaffe seg en rask oversikt over de vesentlige fremskritt i kardiologien i denne perioden på. Lesingen gir gjenkjenning, korreksjon av gamle oppfatninger og overraskelser over ting som er gått en forbi. For alle som er gått trett av vanlige lærebøker, retningslinjer og lesing av oversiktsartikler på nettet, er dette et glimrende alternativ. Landmark papers in cardiovascular medicine egner seg nok best til videre- og etterutdanning.

Det kan reises en del generelle innvendinger. Utvalget av tidsskrifter er svært ensidig - det er en stor dominans av britiske og amerikanske artikler selv på områder der andre beviselig har vært tidligere ute. Ved å avgrense perioden til de siste 40 år utelukker man en serie gjennombrudd innen blant annet invasiv kardiologi og hemodynamikk som kom i tiårene før. Det er en dominans av det siste (og ofte uvesentlige) nye i forhold til det virkelige fundament. Det å velge ti artikler fra hvert felt gjør at det innen noen områder blir tatt med noen ganske dårlige, mens andre åpenbart har måttet prioritere hardt mellom mange gode. Det kan nok diskuteres om metaanalyser bør kvalifisere som «landmark paper». Begrepet «cardiovascular» $\mathrm{i}$ tittelen er misvisende, her er minimalt med «vascular» og også relativt lite om kirurgi. Kardiologien står i sentrum.

I et slikt utvalg vil man automatisk lete etter hva som mangler og hva som kunne vært sløyfet. De skandinaviske innslag er uhyre beskjedne, bare én artikkel er i hovedsak norsk, om 4S-studien. Dopplerdiagnostikk av aortastenose er presentert ved et arbeid fra 1985, mens Liv Hatle og medarbeidere beskrev metoden fullt ut i 1980. Terje Steigen og medarbeideres artikkel om bifurkasjonsstenter ble publisert i 2006, i boken er det tatt med en dårligere artikkel fra 2010. De norske Timolol-, Consensus I- og Norvitstudiene er oversett, i stedet har man valgt senere og dårligere angloamerikanske arbeider.

Men slike ergrelser stimulerer bare til mer lesing. Boken inspirerer til læring og til å gå tilbake til originaldataene. Det er vanskelig å legge den fra seg, dette må bli årets jule- eller påskegave til kardiologer og indremedisinere.

\title{
Knut Rasmussen
}

Hjertemedisinsk avdeling

Universitetet i Troms $\varnothing$

\section{En kardiologisk oppdatering rundt diabetes}

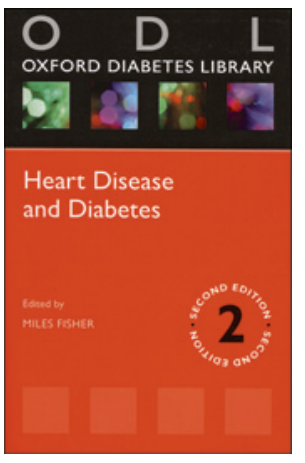

Miles Fisher, red.

Heart disease and diabetes

2. utg. 156 s, tab, ill. Oxford: Oxford University

Press, 2012. Pris GBP 20

ISBN 978-0-19-960456-2

«Diabetes is a state of premature cardiovascular death which is associated with chronic hyperglycaemia and may also be associated with blindness and renal failure.»

Det første kapitlet åpner med disse noe provoserende ordene fra Miles Fisher. Han lanserte dem opprinnelig på British Diabetes Association-møtet i Dublin i 1996. I dag må vi gi ham mer rett enn det vi gjorde den gang, $i$ alle fall når det gjelder diabetes type 2 . Vi blir oppdatert på årsaker, forebygging og behandling av hjertekar-komplikasjoner ved diabetes. Det er en gevinst at litteraturgjennomgangen er god og skiller, så langt det er mulig, mellom diabetes type 1 og type 2 hva gjelder risikofaktorer og behandling.

Målgruppen er primært allmennpraktikere som i stor grad behandler personene med diabetes type 2 , men generelt sett er det også aktuell lesing for alle med spesialitet $\mathrm{i}$ indremedisin, alle diabetessykepleiere, og den burde faktisk stå i bokhyllen til alle diabetesteam rundt om i landet.

Oppbygningen er systematisk, med ti kapitler som enkeltvis tar for seg betydningen av hyperglykemi, hyperlipidemi og hypertensjon i utviklingen av hjerte- og karsykdom. Videre omtales spesifikt koronare syndromer, revaskularisering, hjertesvikt, slag og perifer karsykdom. Avslutningsvis kommer et betimelig kapittel om diabetisk nefropati, en viktig risikotilstand for hjerte- og karsykdom.

Selv for en person som føler seg kompetent innen temaet, er det mye lett tilgjengelig kunnskap å hente i denne boken. Den er kortfattet skrevet (156 sider inklusive stikkordregister), med et enkelt språk. Hvert kapittel starter med en punktvis beskrivelse av nøkkelpunktene i kapitlet, og det blir derfor enkelt å navigere under lesingen. Viktige kliniske intervensjonsundersøkelser er oppsummert på en forbilledlig måte, der de spesifikke funnene fra hver studie (trial) er oppsummert i en enkel tabell og funnene fra alle studiens publikasjoner er inkludert.

Fra en indremedisiners synsvinkel er dette en veldig nyttig bok i det daglige kliniske arbeidet. Spesielt synes jeg gjennomgangen av de kardiologiske betraktningene rundt hypoglykemi, og også asymptomatisk hjertesykdom ved diabetes, er nyttig. Men denne typen publikasjon er også ferskvare. Den har derfor ikke fått med seg årets nye internasjonale retningslinjer for glukosesenkende behandling ved diabetes, lansert av de amerikanske og europeiske diabetesorganisasjonene. Likevel er den svært nyttig lesing, for ikke-kardiologer som en kardiologisk oppdatering rundt diabetes og for kardiologer som en nyttig diabetologisk oppdatering i kardiologien.

Trond Geir Jenssen

Avdeling for organtransplantasjon, fordøyelses- og nyresykdommer Oslo universitetssykehus, Rikshospitalet 